\title{
ROLA PIELĘGNIARKI W PRZYGOTOWANIU PACJENTA W PODESZKYM WIEKU Z CUKRZYCĄ DO SAMOOPIEKI
}

\author{
NURSE ROLE TO CREATE AN ELDERLY PATIENT WITH DIABETES TO SELF-CARE
}

Agata Salwa, Anna Babiarz, Grażyna Nowak-Starz

Instytut Zdrowia Publicznego

Uniwersytet Jana Kochanowskiego w Kielcach

DOI: https://doi.org/10.20883/pielpol.2017.76

\begin{abstract}
STRESZCZENIE
Wstęp. W Polsce na cukrzycę choruje 10-15\% osób powyżej 65. r.ż., a biorąc pod uwagę osoby z podwyższonym, ale nie krytycznym poziomem glukozy, odsetek ten wynosi nawet 25-30\% populacji. Według danych WHO do 2025 roku liczba chorych na cukrzycę na świecie sięgnie 300 milionów przypadków.

Materiał i metody. W niniejszej pracy została zastosowana metoda indywidualnego przypadku (studium przypadku). Celem pracy jest określenie roli pielęgniarki w przygotowaniu pacjenta w podeszłym wieku do samoopieki. Zastosowano technikę wywiadu, obserwacji, przeprowadzenia pomiarów oraz analizy dokumentacji. Badaniem objęto pacjenta w wieku 85 lat, mieszkającego samotnie, chorującego na cukrzycę ponad 20 lat.

Wyniki. Uzyskane wyniki prowadzą do stwierdzenia, że zasadniczymi oczekiwaniami pacjenta wobec pielęgniarki były: nauka samodzielnej kontroli poziomu cukru we krwi, nauka umiejętności samodzielnego wykonywania wstrzyknięć insuliny, jak również wskazanie prawidłowego sposobu dbania o higienę ciała.

Wnioski. Pacjent nie potrafił wykonać prawidłowo czynności manualnych związanych z posługiwaniem się penem, gleukometrem i podawaniem insuliny. Pacjent nie posiada pełnej wiedzy na temat choroby i jej powikłań, a szczególnie braki dotyczą stanów hipoi hiperglikemii. Pacjent nie jest przekonany, że właściwa pielęgnacja stóp w tej jednostce chorobowej ma szczególne znaczenie. Brak odpowiedniej pielęgnacji wynika również z wieku pacjenta, który poprzez swoje niedołęstwo i nieporadność nie jest w stanie właściwie dbać o higienę nie tylko stóp, ale i całego ciała. Edukacja pacjenta i jego rodziny pozwala na podniesienie poczucia świadomości powikłań cukrzycy.
\end{abstract}

SŁOWA KLUCZOWE: pielęgnacja, samoopieka, cukrzyca typu 2, edukacja, profilaktyka.

\section{Wstęp}

Cukrzyca jest jedną z najpoważniejszych chorób cywilizacyjnych współczesnego świata. Chorych wciąż przybywa i aktualnie ich liczba wynosi na świecie około 200 milionów, w Polsce choruje około 2 milionów osób [11]. Z etiologicznego i klinicznego punktu widzenia stanowi ona grupę schorzeń metabolicznych, których podsta-

\begin{abstract}
Introduction. In Poland, diabetes suffers from 10-15\% of people over the age of 65 , and taking into account people with elevated, but not critical glucose levels, this percentage is as high as $25-30 \%$ of the population. According to the WHO, by 2025 the number of diabetics worldwide will reach 300 million cases.

Material and methods. In this paper, the method has been applied on the individual case (case study). The aim of the study is to determine the role of nurses in the preparation of an elderly patient to self-care. The technique of interview, observation, make measurements and analysis of documentation. The study included patients aged 85 years living alone, suffering from diabetes for more than twenty years.

Results. The results lead to the conclusion that the main expectation of the patient to a nurse was to learn self-control blood sugar levels, learning skills of self-inject insulin as well as an indication of the correct way of taking care of body hygiene.

Conclusions. The patient could not perform properly manual tasks associated with the use to the pen, gleukometrem and insulin administration. The patient does not have full knowledge about the disease and its complications, especially shortcomings concerning states of hypo and hyperglycemia. Lack of conviction of the patient on the importance of proper foot care in this disease entity. Lack of proper care also stems from the patient's age, who, through his incompetence and clumsiness is not able to properly take care of hygiene not only the feet but also the entire body. Education of the patient and his family can raise a sense of awareness of the complications of diabetes.
\end{abstract}

KEYWORDS: care, custody, diabetes of type 2, education, prevention.

wową wspólną cechą jest wysoki poziom glukozy we krwi. Dwie podstawowe postacie tej choroby to:

- $\quad$ cukrzyca typu 1 - zwana insulinozależną, która powstaje przede wszystkim w wyniku destrukcji w układzie immunologicznym komórek beta, produkujących insulinę w trzustce. Stanowi okoto 5-10\% wszystkich przypadków; 
- cukrzyca typu 2 - zwana insulinoniezależną, która jest dużo powszechniejsza (90\% przypadków). W głównej mierze jest konsekwencją upośledzenia dwóch podstawowych dla prawidłowego metabolizmu glukozy procesów: wydzielania insuliny i obwodowego działania tego hormonu. Podłoże tych procesów to czynniki genetyczne i środowiskowe [17, 11].

Główną przyczyną inwalidztwa i zgonów w przypadku cukrzycy są jej powikłania, które pojawiają się niemal u wszystkich chorych. Warto jednak dodać, że ryzyko dla życia i zdrowia z powodu tych zaburzeń może być znacznie zredukowane, jeżeli osoba chora zostanie objęta właściwą opieką $[9,15]$.

Cukrzyca ma charakter długotrwały. W proces leczenia zostaje zazwyczaj zaangażowany nie tylko sam chory, ale także jego rodzina. Jest to o tyle uzasadnione, że dzięki samoobserwacji i umiejętnej analizie codziennych informacji i symptomów najpełniej można zwiększyć skuteczność leczenia, a w rezultacie opóźnić ewentualne inwalidztwo czy śmierć z powodu tej choroby lub zapobiec im $[3,9]$.

Włączenie rodziny w proces edukacji umożliwia poznanie i zrozumienie problemów pacjenta przez otoczenie i czynne współuczestnictwo w procesie leczenia, co korzystnie wpływa na motywacje chorego. Znaczący wpływ ma także rozwój edukacji zdrowotnej prowadzonej przez zespół terapeutyczny, której niedostatek jest odczuwany zarówno przez pacjentów, jak i ich rodziny [1].

\section{Materiał i metody}

Celem badania była próba określenia roli pielęgniarki w przygotowaniu pacjenta w podeszłym wieku z cukrzycą do samoopieki.

Do tak sformułowanego celu głównego sformułowano następujące zasadnicze pytanie badawcze: „Jaka jest rola pielęgniarki w przygotowaniu pacjenta w podeszłym wieku z cukrzycą do samoopieki?".

Następnie sformułowano pytania szczegółowe:

1) „Czy pacjent potrafi wykonać pomiar glukozy?”,

2) „Czy umie wykonać iniekcję insuliny i czy zna miejsca jej podania?",

3) „Czy zna i potrafi rozpoznać objawy niedocukrzenia i przecukrzenia?",

4) „Czy rozumie konieczność właściwej pielęgnacji stóp?",

5) „Czy jest świadomy ryzyka powikłań, które niesie ze sobą choroba?",

6) „Czy zna zasady diety cukrzycowej?”.

W niniejszej pracy została zastosowana metoda indywidualnego przypadku (studium przypadku). W celu pozyskania danych, identyfikacji problemów pielęgniar- skich, sposobów ich rozwiązywania oraz dokonywania oceny efektywności podjętych działań zastosowano poniższe techniki badawcze:

- wywiad,

- obserwację,

- pomiar parametrów życiowych,

- analizę dokumentacji.

Narzędzia badawcze, które zostały wykorzystane w tej pracy, to:

- $\quad$ przewodnik do gromadzenia danych o pacjencie,

- zgłoszenie do objęcia pielęgniarską opieką domową w $\mathrm{POZ}$,

- $\quad$ indywidualna karta opieki pielęgniarskiej w POZ,

- $\quad$ skala oceny rozwoju odleżyn (skala Barthel).

Badaniem opisanym $w$ tej pracy objęto pacjenta J.B. w wieku 85 lat zamieszkałego w Kielcach. Badanie zostało przeprowadzone w dniach 19-31 października 2015 roku, podczas zmiany rannej i popołudniowej. Kontakt z pacjentem był bardzo dobry, chory wyraził zgodę na przeprowadzenie badania. Syn badanego mieszka w Kielcach, zaś córka - w Ostrowcu Świętokrzyskim. Z obojgiem łączą go zażyłe kontakty, czuje się im potrzebny, dzieci interesują się jego losem. Codziennie odwiedza go syn z wnukami, a córka co 2 tygodnie lub zabiera go do siebie na kilka dni. Zarówno pacjent, jak i jego rodzina byli bardzo zainteresowani każdą informacją i wskazówką dotyczącą życia z cukrzycą, rozwiązywaniem problemów, radzeniem sobie w przypadku powikłań.

Badanie przeprowadzane zostało w godzinach porannych między 7.30 a 10.30 oraz popołudniowych od 15.00 do 17.00 .

Choroba to dla Pana Juliana „niedogodność życiowa”. Pochłania dużo jego czasu i uwagi, z czym nie może się pogodzić. Jest osobą otyłą, nigdy nie palił papierosów, alkohol pił tylko sporadycznie przy okazji uroczystości rodzinnych, natomiast zawsze lubił i lubi „dobrze zjeść”. Nigdy nie narzekał na swoje zdrowie, jakieś drobne niedyspozycje bagatelizował i uważał, że to z przemęczenia. Ale około 20 lat temu to przemęczenie zaczęło trwać zbyt długo. W ciągu dnia potrzebował czasu na drzemki, stał się apatyczny, mało aktywny, stracił kilka kilogramów na wadze, wejście po schodach sprawiało mu trudność, szybko się męczył. Mimo nalegań żony nie chciał pójść do lekarza, a ponieważ była to pora jesienna, uważał, że wszystkie te niedomagania związane są z przesileniem jesienno-zimowym. Do lekarza udał się dopiero wtedy, gdy zaczął mieć zawroty głowy i zaniepokoił go fakt, że aby wejść na drugie piętro, musiał przystawać, żeby odpocząć. Po zbadaniu i wykonaniu analizy krwi diagnoza lekarza brzmiała - cukrzyca.

Początkowo badany uważał, że diagnoza to pomyłka, że to niemożliwe, przecież on jest „okazem zdro- 
wia”, cukru nie używał, od słodyczy stronił. Owszem miał nieznacznie zawyżone wartości lipidogramu czy podwyższone ciśnienie krwi, ale nie było to nic nazbyt poważnego. Dopóki żyła żona, badany tak bardzo dotkliwie tego nie odczuwał, bo ona dbała o to, aby regularnie przyjmował lekarstwa, zmieniła dietę, wiedziała, co mąż może zjeść, a czego powinien się wystrzegać (co nie zawsze mu się podobało). Żona pamiętała także o terminach wizyt kontrolnych, przypominała o pomiarach cukru, ciśnienia. Okazało się, że ta choroba nie jest jednak taka straszna. Badany nadal poświęcał się malarstwu, pisaniu, kondycja fizyczna uległa poprawie. Początkowo jego leczenie polegało na przyjmowaniu tabletek, stosowaniu diety, wykluczeniu używek. Z czasem jednak to nie wystarczało i do leczenia wdrożona została insulina. Kiedy zmarła żona i został sam z chorobą, zaczął na nowo odkrywać, jak dużo czasu trzeba niniejszej przypadłości poświęcać. Musiał sam myśleć o przyjmowaniu leków, o stałych porach przyjmowania insuliny, o właściwej diecie, o chodzeniu do lekarzy, o przestrzeganiu higieny stóp (na co zawsze zwracała mu uwagę żona). Badany nauczył się podawać sobie samemu insulinę (warto dodać, że do tej pory pomiary cukru sprawiają mu dyskomfort), lecz zawsze ma opory przed wykonaniem zastrzyku.

Na początku bardzo pomogły mu dzieci, wnuki, ale one - zajęte swoją pracą, szkołą, studiami - nie mogły bez końca mu pomagać. Ponieważ nie chciał z nimi zamieszkać, musiał sam radzić sobie z chorobą. Przez lata udawało mu się to. Z czasem jednak pojawiły się problemy ze wzrokiem, ciśnienie zaczęło się podnosić, miewał (nadal miewa) problemy z układem moczowym, ma trudności w pracach manipulacyjnych, bo palce ma „drętwe i obolałe”, skarży się na bóle kończyn dolnych (zwłaszcza przy chodzeniu), także na bóle kręgosłupa. Na początku tego roku zaczęły doskwierać mu bóle w klatce piersiowej, silna duszność, a przy tym wysoki cukier. Trafił na kardiologiczny oddział szpitalny, gdzie wszczepiono mu kardiostymulator.

\section{Wyniki}

Z analizy dokumentacji medycznej pacjenta wynika, że oprócz cukrzycy rozpoznano także: nadciśnienie tętnicze, miażdżycę, kamicę pęcherzyka żółciowego, przerost gruczołu krokowego, wystąpiły powikłania w postaci retinopatii, nefropatii, polineuropatii.

W trakcie przeprowadzanego badania poszczególne pomiary pacjenta wynosiły:

- glukoza (mierzona glukometrem) - 116-167 mg/ dl i utrzymywała się w tym przedziale;

- ciśnienie krwi utrzymywało się w przedziale od 140/75 mmHg do 175/105 mmHg;
- $\quad$ tętno od $70 \mathrm{u} / \mathrm{min}$ do $84 \mathrm{u} / \mathrm{min}$, dobrze wyczuwalne, miarowe;

- częstość oddechów 16-18/min z lekką dusznością.

Przy wzroście $161 \mathrm{~cm}$ pacjent waży $97,5 \mathrm{~kg}$. Po przeliczeniu wskaźnik masy ciała (BMI) - masa ciała podzielona przez wzrost w metrach do kwadratu - wyniósł 37,64 $\mathrm{kg} / \mathrm{m}^{2}$ (prawidłowy wskaźnik dla kobiet: 19 do $23 \mathrm{~kg} / \mathrm{m}^{2}$, dla mężczyzn: 20 do 24 kg/m²; wartość BMI powyżej 30 to znacząca nadwaga).

Z obserwacji i wywiadu wynika, iż:

1) stan świadomości pacjenta jest pełny, kontakt słowny prawidłowy;

2) skóra czysta, bez zmian grzybiczych, na stopach skóra zgrubiała, obrzęknięta, widoczne odciski, zrogowaciałe paznokcie, wyraźnie odciśnięte ślady skarpetek;

3) na podudziach widoczne żylaki;

4) okresowo u pacjenta występują dolegliwości ze strony układu pokarmowego w postaci zaparć, dyspepsji, niekiedy dużego pragnienia;

5) ze strony układu moczowego częste infekcje;

6) występują zaburzenia widzenia w postaci rozmazanego obrazu;

7) dolegliwości bólowe kręgosłupa i nóg, zwłaszcza przy wstawaniu, schylaniu się;

8) stan emocjonalny pacjenta ulega częstym zmianom;

9) pacjent potrzebuje pomocy w czynnościach wymagających dużego wysiłku (niektóre czynności samoobsługowe), poza tym jest samodzielny.

Analiza zebranych danych oraz rozpoznanie indywidualnych i podstawowych potrzeb zdrowotnych chorego stanowi punkt wyjścia do podjęcia odpowiednich działań pielęgniarskich.

W niniejszej pracy rozpoznano następujące diagnozy pielęgniarskie:

1) ryzyko wystąpienia zespołu stopy cukrzycowej z powodu niewłaściwej pielęgnacji stóp;

2) ryzyko pogorszenia widzenia spowodowane retinopatią;

3) możliwość błędnych wyników pomiarów cukru wskutek niedostatecznej wiedzy pacjenta na temat techniki ich wykonywania;

4) nieumiejętność podawania insuliny wskutek braku dostatecznej wiedzy pacjenta;

5) możliwość wystąpienia śpiączki hipo- lub hiperglikemicznej wskutek niedostatecznej wiedzy pacjenta o objawach i sytuacjach mogących doprowadzić do tych powikłań;

6) lęk przed wystąpieniem hipoglikemii;

7) dolegliwości bólowe kończyn dolnych spowodowane wysiłkiem fizycznym lub pozostawaniem zbyt długo w jednej pozycji; 
8) zagrożenie wystąpieniem choroby zakrzepowo-zatorowej lub owrzodzenia kończyn dolnych z powodu żylaków;

9) ryzyko występowania wysokich poziomów cukru z powodu niedostatecznej znajomości przez pacjenta zasad diety cukrzycowej;

10) niepokój rodziny o zdrowie i bezpieczeństwo pacjenta z powodu jego uporu, aby mieszkać samodzielnie;

11) dyskomfort pacjenta i niechęć do wychodzenia z domu spowodowane częstym oddawaniem moczu;

12) dyskomfort pacjenta $z$ powodu nadmiernego świądu skóry;

13) brak dostatecznej wiedzy pacjenta na temat ryzyka wystąpienia powikłań krążeniowych z powodu nadciśnienia tętniczego;

14) możliwość błędnych wyników pomiarów ciśnienia tętniczego krwi z powodu niedostatecznej znajomości przez pacjenta zasad prawidłowego wykonywania pomiaru;

15) złe samopoczucie pacjenta z powodu często występującej dyspepsji;

16) ustawiczny dyskomfort pacjenta $z$ powodu ograniczonej zdolności do malowania obrazów spowodowany zaburzonym czuciem i bólem palców u rąk.

Po ustaleniu diagnozy pielęgniarskiej zastosowano opracowany plan opieki nad pacjentem; w ramach tego planu uwzględniono: problem, cel opieki, a także ocenę wyników. Rezultaty zastosowanej opieki nad pacjentem przedstawiają się następująco:

1) stopa cukrzycowa nie wystąpiła;

2) widzenie nie pogorszyło się;

3) pacjent został wyedukowany w zakresie prawidłowego wykonywania pomiarów cukru;

4) pacjent został wyedukowany w zakresie prawidłowego podawania insuliny;

5) pacjent zna objawy i sytuacje mogące wywołać stan śpiączki hipo- lub hiperglikemicznej;

6) ponadto wie, jak im zapobiegać i wie, jak sobie radzić w momencie ich pojawienia się;

7) lęk został zminimalizowany;

8) dolegliwości bólowe zmniejszyły się;

9) zagrożenia wystąpieniem choroby zatorowo-zakrzepowej lub owrzodzenia nie wystąpiły;

10) ryzyko występowania wysokich cukrów zostato zminimalizowane. Pacjent zna zasady diety cukrzycowej;

11) rodzina jest spokojna o zdrowie i bezpieczeństwo pacjenta;

12) dyskomfort spowodowany częstym oddawaniem moczu ustąpił;
13) świąd skóry został ograniczony. Komfort życia pacjenta uległ poprawie;

14) pacjent został wyedukowany w zakresie ograniczenia ryzyka powikłań krążeniowych z powodu nadciśnienia tętniczego;

15) pacjent zna zasady prawidłowego mierzenia ciśnienia;

16) samopoczucie pacjenta uległo poprawie, częstość występowania dyspepsji uległa zmniejszeniu.

\section{Dyskusja}

Przy wyborze tematu kierowano się przekonaniem, że cukrzyca, której mianem określana jest liczna grupa chorób i zaburzeń metabolicznych (objawiających się patologiczną hiperglikemią na czczo, po posiłkach lub między posiłkami), dotyczy osób w różnym wieku. Według Tatonia „wskaźnik chorobowości z powodu cukrzycy wzrasta głównie w wyniku zwiększenia się liczby chorych na cukrzycę typu 2" [32].

Według Buławskiej i Talagi historia tej choroby sięga 3,5 tysiąca lat, ale do tej pory nie udało się znaleźć skutecznego sposobu jej wyleczenia. Szacuje się, że w Polsce choruje około 2 milionów, na świecie około 200 milionów ludzi. Przypuszcza się, że w XXI wieku liczba przypadków cukrzycy na świecie wzrośnie o ponad $200 \%$ [3].

Starość jest nieuniknionym etapem w życiu każdego człowieka. Wraz z postępem medycyny wydłuża się długość życia zarówno kobiet, jak i mężczyzn. Starość to również ograniczenie sprawności fizycznej i psychicznej człowieka. W perspektywie rosnącej liczby osób w zaawansowanym wieku na personelu medycznym ciąży odpowiedzialność dostosowania opieki, pielęgnacji, pomocy psychospołecznej do indywidualnych potrzeb i możliwości osób w podeszłym wieku.

Człowiek stary to często osoba zniedołężniała, mająca problemy związane z przyswajaniem nowej wiedzy. Dotyczy to również wiedzy w zakresie chorób, powikłań, które niosą ze sobą, właściwej pielęgnacji, przestrzegania zaleceń pielęgniarki i lekarza. Jest to etap w życiu człowieka, który wymaga reorientacji, akceptacji nowych zadań, obowiązków i praw, nawyków [8, 10].

Cukrzyca wieku podeszłego jest jedną z chorób stanowiących najpoważniejsze wyzwania zdrowotne współczesnego świata. Prowadzi ona do powstawania wielu powikłań w obrębie narządów i układów oraz powoduje skrócenie okresu przeżycia. Osoba z cukrzycą w podeszłym wieku to bardzo często osoba zaniepokojona o los swój i rodziny, często nieposiadająca wiedzy, jak sobie radzić z tak poważną chorobą, jak przeciwdziałać jej następstwom. To także osoba nieznająca zasad diety cukrzycowej, nieposiadająca wiedzy w zakresie samokontroli i samoopieki [11, 12]. Mając na uwadze powyższe, ważnym elementem opieki pielęgniarskiej, 
a szczególnie tej w ramach opieki środowiskowo-rodzinnej, jest dostarczenie odpowiedniej wiedzy samemu pacjentowi i jego rodzinie oraz podniesienie ich umiejętności, co pozwoli choremu samodzielnie i godnie funkcjonować w życiu społecznym.

W procesie opieki nad pacjentem z cukrzycą napotyka się liczne problemy w zakresie pielęgnacji i samoopieki. Odpowiadając na pierwsze i drugie pytanie szczegółowe, stwierdzono, że pacjent nie potrafił wykonać prawidłowo czynności manualnych związanych z posługiwaniem się penem, gleukometrem i podawaniem insuliny. W przypadku trzeciego pytania należy stwierdzić, że pacjent nie posiada pełnej wiedzy na temat choroby i jej powikłań, a szczególnie braki dotyczą stanów hipo- i hiperglikemii. Odpowiadając na czwarte pytanie szczegółowe, stwierdzono, że pacjent nie jest przekonany, iż właściwa pielęgnacja stóp w tej jednostce chorobowej ma szczególne znaczenie. Można także stwierdzić, że brak odpowiedniej pielęgnacji wynika również z wieku pacjenta, który z powodu trudności motorycznych nie jest w stanie właściwie dbać o higienę nie tylko stóp, ale i całego ciała. W odpowiedzi na piąte pytanie szczegółowe należy podkreślić, że edukacja pacjenta i jego rodziny pozwala na podniesienie poczucia świadomości powikłań cukrzycy. Dlatego głównym zadaniem pielęgniarki jest przekazywanie wiedzy i umiejętności samokontroli, umożliwiających ciągłe i skuteczne kontrolowanie cukrzycy oraz samodzielne funkcjonowanie w codziennym życiu. Szczególną rolę w tym zakresie odgrywa pielęgniarka środowiskowo-rodzinna. Odpowiadając na ostatnie pytanie szczegółowe, należy stwierdzić, że pacjent nie znał wszystkich zasad diety cukrzycowej. W związku z tym niezbędne było podjęcie działań edukacyjnych.

Podsumowując, należy przypomnieć, że cukrzyca jest uważana za jedną z najpoważniejszych chorób cywilizacyjnych współczesnego świata. Pomimo stosunkowo szybkiego rozwoju medycyny liczba chorych wciąż rośnie. Wielu chorych to osoby w podeszłym wieku. W tej perspektywie podjęty w pracy temat jest szczególnie aktualny.

Przeprowadzone badania i uzyskane wyniki pozwalają sformułować wniosek, iż istnieje realna konieczność uświadamiania pielęgniarkom (w szczególności środowiskowo-rodzinnym) ich rzeczywistej roli w edukacji osób z cukrzycą. W szczególności dotyczy to osób starszych cierpiących na powyższą chorobę. Temat ten jest bowiem traktowany zdecydowanie zbyt powierzchownie.

\section{Wnioski}

1. Pacjent nie potrafił wykonać prawidłowo czynności manualnych związanych z posługiwaniem się penem, gleukometrem i podawaniem insuliny.

2. Pacjent nie ma pełnej wiedzy na temat choroby i jej powikłań, a szczególnie braki dotyczą stanów hipo- i hiperglikemii.
3. Pacjent nie jest przekonany, że właściwa pielęgnacja stóp w tej jednostce chorobowej ma szczególne znaczenie.

4. Brak odpowiedniej pielęgnacji wynika również z wieku pacjenta, który poprzez swoje niedołęstwo i nieporadność nie jest w stanie właściwie dbać o higienę nie tylko stóp, ale i całego ciała.

5. Edukacja pacjenta i jego rodziny pozwala na podniesienie poczucia świadomości powikłań cukrzycy.

6. Pacjent nie znał wszystkich zasad diety cukrzycowej. W związku z tym niezbędne było podjęcie działań edukacyjnych.

\section{Piśmiennictwo}

1. Abramczyk A. Profilaktyka i wczesne wykrywanie cukrzycy w praktyce pielęgniarki środowiskowo-rodzinnej. Wrocław: Wyd. A\&A Optimed; 2002.

2. Biercewicz M. Pielęgniarstwo w geriatrii. W: Biercewicz M, Szewczyk MT, Ślusarz R (red.). Pielęgniarstwo w geriatrii. Wybrane zagadnienia $z$ zakresu pielęgniarstw specjalistycznych. Warszawa: Borgis; 2006.

3. Karnafel W. Stopa cukrzycowa. W: Wardyn K, Karnafel W, Życińska K (red.). Diabetologia. Lublin: Czelej; 2008.

4. Kędziora-Kornatowska K, Muszalik M (red.). Kompendium pielęgnowania pacjentów w starszym wieku. Podręcznik dla studentów i absolwentów kierunku pielęgniarstwo. Lublin: Czelej; 2007.

5. Kociuba K, Dobrowolska B. Etyczne aspekty domowej opieki pielęgniarskiej nad pacjentem w podeszłym wieku. Piel XXI w. 2008; 4: 25-28.

6. Kózka M, Płaszewska-Żywko L. Diagnozy i interwencje pielęgniarskie. Podręcznik dla studiów medycznych. Warszawa: PZWL; 2007.

7. Kurowska K, Centkowska U. Pacjent z przewlekłym miażdżycowym niedokrwieniem kończyn dolnych. Mag Piel Położ. 2007; 10: 14-15.

8. Kwapisz U. Chory z odleżynami. Mag Piel Położ. 2005; 4: 22.

9. Łagoda K, Sierżantowicz R. Zmiany skórne w cukrzycy. Mag Piel Położ. 2005; 4: 31-32.

10. Łagoda K, Sierżantowicz R. Zakażenia grzybicze stóp. Mag Piel Położ. 2005; 5: 18-20.

11. Otto-Buczkowska E. Cukrzyca, patogeneza, diagnostyka, leczenie: wybrane zagadnienia. Warszawa: Borgis; 2005.

12. Pączek $L$ et al. Choroby wewnętrzne. Podręcznik dla studentów pielęgniarstwa i położnictwa. Warszawa: PZWL; 2006.

Artykuł przyjęty do redakcji: 09.02.2017

Artykuł przyjęty do publikacji: 07.03.2017

Źródło finansowania: Praca nie jest finansowana z żadnego źródła. Konflikt interesów: Autorzy deklarują brak konfliktu interesów.

\author{
Adres do korespondencji: \\ Agata Salwa \\ Brynica 19 \\ 26-065 Piekoszów \\ tel. kom.: 530168129 \\ e-mail: salwaagatka@gmail.com
}

